Article

\title{
Is the Fiscal Deficit of ASEAN Alarming? Evidence from Fiscal Deficit Consequences and Contribution towards Sustainable Economic Growth
}

\author{
Maran Marimuthu ${ }^{1}$, Hanana Khan ${ }^{1,2, *}$ and Romana Bangash ${ }^{3}$ \\ 1 Department of Management and Humanities, Universiti Teknologi PETRONAS, \\ Seri Iskandar 32610, Malaysia; maran.marimuthu@utp.edu.my \\ 2 Department of Economics, Kohat University of Science and Technology, Kohat 26000, Pakistan \\ 3 Institute of Management Sciences (IM I Sciences), Peshawar 25000, Pakistan; \\ romana.bangash@imsciences.edu.pk \\ * Correspondence: hanana_17005179@utp.edu.my
}

Citation: Marimuthu, M.; Khan, H.; Bangash, R. Is the Fiscal Deficit of ASEAN Alarming? Evidence from Fiscal Deficit Consequences and Contribution towards Sustainable Economic Growth. Sustainability 2021, 13, 10045. https://doi.org/10.3390/ su131810045

Academic Editor: Mihaela Onofrei

Received: 21 August 2021

Accepted: 1 September 2021

Published: 8 September 2021

Publisher's Note: MDPI stays neutral with regard to jurisdictional claims in published maps and institutional affiliations.

Copyright: (c) 2021 by the authors. Licensee MDPI, Basel, Switzerland. This article is an open access article distributed under the terms and conditions of the Creative Commons Attribution (CC BY) license (https:// creativecommons.org/licenses/by/ $4.0 /)$.

\begin{abstract}
The Association of Southeast Asian Nations (ASEAN) has faced a persistent fiscal deficit for the last three decades. In the vast literature, a question is still arising: is ASEAN's fiscal deficit alarming? This study explores the fiscal deficit with different perspectives to provide guidelines for policymakers to answer this question. For this purpose, we offer fiscal causal hypotheses estimates, including the contribution of Government expenditures (GEs) and Government revenues (GRs) towards sustainable economic growth; we then evaluated two additional deficit hypotheses, the impact of fiscal deficit and deficit financing on inflation. This empirical analysis covered annual financial data for the years 1990 to 2019 of ten member countries of ASEAN by applying panel econometric techniques, which include unit root Levin, Lin, and Chu (LLC) and Im, Pesaran, and Shin (IPS) tests; the panel autoregressive distributed lag (ARDL) model for cointegration; and the Dumitrescu-Hurlin (DH) test for causality. The findings revealed that government expenditures contribute more towards sustainable economic growth while government revenues are inversely related to growth in the long run. The DH causality test supported the fiscal synchronization hypothesis and current account targeting hypothesis in ASEAN. The interest rate is found as a moderator between fiscal and current account deficits. Furthermore, the findings showed that the fiscal deficit of ASEAN could generate inflation while relying on outstanding debt. Overall, our findings concluded that the fiscal deficit of ASEAN is alarming based on the behavior of government revenues, interest rate dynamics, political stability, and outstanding debt in deficit financing.
\end{abstract}

Keywords: fiscal and current account deficits; twin deficit hypotheses; fiscal causal hypotheses; sustainable economic growth; inflation; panel unit root; panel cointegration; panel DH causality

\section{Introduction}

Economic research and public policymakers emphasized fiscal policy as a stabilization tool in the last three decades due to the downturn in fiscal deficit during the Asian Financial Crisis (AFC'97) and the Global Financial Crisis (GFC'07). The recent academic pendulum is swinging towards the consolidation of the fiscal deficit. The post-crisis experiences and recent economic research address the importance and effectiveness of fiscal balance as a tool for the long-term and short-term impacts of financial decisions and economic policies.

Recently, economists and researchers have reported their findings on ASEAN's economy, provided suggestions, and created policy guidelines [1-6]. The fiscal componentsi.e., government expenditures, government revenues, and deficit financing-play an essential role in the fiscal policy of ASEAN. For the last two decades, government expenditure (GE) contributions to the GDP have been stable in Southeast Asian nations. However, some members of ASEAN have faced notable changes in GE from 2006 to 2016. For example, 
Brunei's expenditures increased by 9.8 percent; Myanmar and Cambodia experienced significant increases in their government expenditures by 7.6 and 7.1 percent, respectively. Malaysia and Indonesia are the only ASEAN countries where expenditures decreased, by 2.9 and 1.9 percent, respectively.

Government revenues (GRs) are the second component of fiscal policy. Sources of government revenue are taxation, social contribution, and other revenues such as fees, rent, fines, income from property, and sales. The primary sources of revenue through taxation in ASEAN are standard corporate income tax, the top personal income tax rate, nonresident withholding tax, indirect tax, and capital gains. The nonresident withholding tax includes dividends, royalties, and interest rates. In ASEAN, taxation is a significant source of government revenue [4,7]. Lau and Yip [8] provided evidence that before GFC, the fiscal deficit had negative impacts on the economic growth of Southeast Asia; after GFC or in the post-crisis period, fiscal deficit behavior was growth-enhancing.

Further, it has been reported that the relationship between fiscal deficit and economic growth depends on fiscal components. An untreated fiscal deficit can cause further economic problems, such as inflation, current account deficit, and interest rate fluctuations [9]. There is a vast debate among economists concerning such economic problems that are caused by a fiscal deficit. The two most dominant consequences are the twin deficit hypotheses and inflation. The twin deficit hypothesis assumes that a fiscal deficit may cause a current account deficit, so in this way, the economy is facing a double deficit, known as the twin deficit hypothesis. It has important implications for long-term economic growth in an economy. The fiscal expansion can worsen both the current account and the exchange rate appreciation, resulting in an imbalance between the current and fiscal deficits that can disrupt economic activities.

Inflation plays a vital role in fiscal consolidation. One of the views of macroeconomics is that a fiscal deficit can be a significant cause of inflation. Primarily, it is tricky to handle inflation, which is random and dynamic in emerging and developing economies. Several factors can cause inflation in an economy. One of those factors is the fiscal deficit. The fiscal deficit and inflation are serious economic problems in emerging economies, even though less consideration is given to the relationship between fiscal deficit and inflation. A fiscal deficit can cause inflation in two ways. First, government authorities raise tax revenues and minimize the fiscal deficit. Therefore, high taxes can increase the cost of production, which can increase pressure on the market price level. This price increase is from the supply side. The second way is from the demand side when the central bank increases the money supply to fill the gap in fiscal deficit [10]. The government authorities can utilize ways and means to finance the fiscal deficit, such as outstanding debt and printing new money. However, each mode of financing has its shortcomings and challenges along with the overall fiscal deficit. For instance, by increasing government borrowing, the public can face high taxation and interest rates in the future to repay the borrowed finance. Similarly, printing new money by central banks would induce high pressure on the money supply, which may perhaps further cause inflation [11]. Therefore, the policymakers need empirical evidence of various trends of economic variables to come to a consensus regarding the suitable sources of financing for a fiscal deficit. However, it is unclear which sources of financing are less inflationary when used for financing the fiscal deficit.

Political stability and economic growth are two important factors contributing to budget allocation (e.g., the public health sector, infrastructure, and education) [12]. Government revenues can be affected by political stability, corruption, and the quality of policies. Stable political and economic conditions are the two factors that determine the realization of revenue. There is no doubt that economic activity is backed by the stability of political and social conditions, which creates opportunities for government authorities to maximize their revenue [13,14].

Previous studies argued about fiscal deficit and economic growth with a different perspective, i.e., a fiscal deficit can be faced by any developed or developing economies, but this is still doubtful in ASEAN and hence poses a question: is the fiscal deficit alarming? An 
alarming fiscal deficit is a warning sign for policymakers and investors. There is a need to look at those consequences that can result from the fiscal deficit in ASEAN. Therefore, this study aims to explore a fiscal deficit with different perspectives to provide guidelines for policymakers. The first objective of this study is to explore the fiscal causal hypotheses and the contribution of government expenditures and revenues towards sustainable economic growth. The second objective is to investigate the relationship between fiscal and current account deficits in ASEAN. The third objective is to evaluate the impact of a fiscal deficit and its sources of finance on inflation along with the moderating role of political stability.

The rest of the paper is arranged as follows. Section 2 discusses the previous related studies, Section 3 explains the materials and methods, including the data, variables, models, and the econometric techniques used in the estimation, and Section 4 presents the empirical findings and discussion. Finally, Section 5 delivers the conclusion and policy recommendations.

\section{Literature Review}

Numerous empirical studies have investigated the fiscal causal hypotheses for individual members or panels of some members of ASEAN, such as Karim et al. [15], who tested the fiscal causal hypotheses in ASEAN-5, and found that the expenditure dominance hypothesis is supported in Malaysia, Indonesia, and the Philippines. In contrast, the revenue dominance hypothesis is validated in Singapore and Thailand. Magazzino [16] studied the fiscal causal hypotheses in ASEAN-10 by employing panel Granger causality. Their results have revealed that the tax-and-spend hypothesis is true in five ASEAN economies. Saysombath and Kyophilavong [17] investigated the causal relationship between GR and GE in LAOS from 1980 to 2010. The results have shown a long-run connection between government expenditures and revenues, and the expenditure dominance hypotheses are supported in LAOS. Likewise, Jalil and Harun [18] reported on two states of Malaysia, namely, Penang and Kelantan, whereas the ARDL bounds test was applied for cointegration relationships and reported that the tax-spend hypothesis is supported in Kelantan, while in Penang, no such causal association exists regarding expenditures and revenues in the short run, which is known as the institutional separation hypothesis.

Similarly, Jiranyakul [19] has found that the spend-tax hypothesis is valid in the case of Thailand. Narayan [20] estimated the fiscal causality in Southeast Asian countries, i.e., Indonesia and Singapore, using the ARDL technique. The study revealed that the taxspend hypothesis manifests in Indonesia and Singapore. Obeng [21] analyzed the long-run relationship between revenues and expenditures by employing ordinary least squares and Vector Auto-Regressive (VAR) methods and reported a unidirectional causality from revenues to expenditures, supporting the revenue dominance hypothesis. Mele, Quarto, and Abbafati [22] analyzed the causal connection between government expenditures and revenues in Malaysia over the period from 1985 to 2016. The authors reported that the expenditure dominance hypothesis is evident. Hence, it concluded that an increase in taxation had reduced disposable income, further affecting savings. It is better to consider the expenditure level while specifying the tax rate.

The findings in previous studies regarding government expenditures and their impact on economic growth are controversial and lacking in the ASEAN region. Few studies [23-25] have demonstrated a significant and positive connection between GE and economic growth. In contrast, few studies [26,27] found a negative association, while some studies [28] have reported no connection at all. Tang et al. [5] have discussed the significant impact of GE on economic growth in five ASEAN economies. Likewise, a few ASEAN economies reported mixed results regarding GE and economic growth, indicating negative associations in Malaysia, Singapore, and Thailand [29]. The findings of Samudram et al. [30] indicated a long-run bidirectional causality for GE and gross national product in Malaysia. In the last three decades, most developed and developing economies have faced a persistent fiscal deficit. Many economies have faced challenges of high fiscal deficit and volatility [31]. Baharumshah et al. [32] investigated the twin deficit hypothesis in ASEAN-5 (Indonesia, Malaysia, the Philippines, Thailand, and Singapore) by considering FD, CAD, and private 
investment. The reported results showed that the twin deficit hypothesis holds in Malaysia, Thailand, and the Philippines, while private investment is completely crowding out due to government expenditures. Lau et al. [33] reported bidirectional causality between fiscal and current account deficits in the Philippines, twin deficit in Malaysia and Thailand, and unidirectional causality from a current account deficit to a fiscal deficit in Indonesia. Magazzino [34] found the predominance of Ricardian equivalence in Southeast Asia.

Previous studies have reported fiscal deficit challenges faced by other countries; for instance, Bucevska [35] empirically examined the validity of the twin deficit hypothesis in the Republic of North Macedonia by covering the period from the first quarter of 2005 to the fourth quarter of 2017. The study employed Granger causality, vector autoregressive (VAR), and vector error correction model (VECM). The findings revealed a causal relationship between fiscal and current account deficit; the twin deficit hypothesis is supported in North Macedonia. The study suggested that policymakers should not only consider reducing the Autoregressive distributed lag model (PARDL) with quarterly data from 2000Q1 to 2019Q4. The reported findings disclosed that the twin deficit effect is dampening up to a certain threshold level. Beyond the threshold level, both deficits can affect each other. Janko [36] examined long-run and short-run relationships between fiscal and current account deficits in Canada, and the results align with the twin deficit hypothesis. Sharma and Mittal [37] observed India's fiscal deficit and inflation nexus from the periods 1980-1981 and 2016-2017 by using ARDL and nonlinear ARDL. The results showed no evidence of a linear relationship between fiscal deficit and inflation. A nonlinear relationship exists among these variables in India, which found evidence of the fiscal theory of price. The significant policy implication of their study is to consolidate the fiscal deficit. In addition, the central bank of India must regulate lending interest rates so that the combination of fiscal and monetary policy can be applied to control inflation in India.

One of the significant factors of fiscal deficit instability is political behaviors, as recent studies stated that if political stability (PS) is moderating, then fiscal deficit leads to inflation, notably in developing and rising economies [38,39]. In developing economies, the dominance of political stability mostly leads to a large fiscal deficit [40]. Political stability and good governance are the explanatory variables to represent political behavior. Franzese [41] discussed that political bodies only consider policies that can benefit them in terms of winning elections. The government cycle in election years, which mainly relies on these policies, generally presents higher fiscal deficits. Telatar et al. [42] estimated the impact of political factors on inflation by using a dynamic panel data approach. The empirical results indicated that low political instability generates low inflation in developed and low-inflation economies, while in high inflation developing countries, political instability is influential and significantly affects inflation. Aisen and Veiga [43] and Telatar et al. [42] reported a significant connection with soaring inflation. Asteriou and Siriopoulos [44] reported that an uncertain socio-political situation strongly negatively influences economic growth. Furthermore, Asteriou and colleagues [45] have developed a small econometric model for Greece's economy and concluded that high public debt to GDP ratio worsens the country's fiscal position. Hence, a high debt outstanding can be alarming for policymakers.

Previous research on the fiscal deficit has mainly been conducted outside of ASEAN, either in Asia or other developing countries. Additionally, the past studies conducted on ASEAN [46-50] have no extensive empirical evidence of investigating the fiscal deficit, whether it is alarming or not. A fiscal deficit is a warning sign for policymakers and investors. There is a need to look at those consequences that can result from an alarming fiscal deficit. This study is unique as it investigates the alarming nature of the fiscal deficit. For this purpose, the consequences of the fiscal deficit, such as the current account deficit, inflation, and the moderating role of political stability and causality among the fiscal components, are to be estimated to answer the question: is ASEAN's fiscal deficit alarming? 


\section{Materials and Methods}

\subsection{Data and Variables}

This study analyzed the annual panel time-series data from 1990 to 2019 for ten ASEAN members, including Brunei, Cambodia, Indonesia, Lao PDR, Malaysia, Myanmar, the Philippines, Singapore, Thailand, and Vietnam. The time is based on the availability of data, and this study is based on the last three decades of ASEAN to analyze the fiscal deficit based on its consequences. The data were acquired from authentic economic data sources, such as the World Bank and Asian Development Bank databases, which are publicly available. Total government revenue (GR), total government expenditure (GE), gross domestic product (GDP), inflation (CPI), political stability (PS), current account deficit (CAD), fiscal deficit (FD), exchange rate (EXC), and interest rate (IR) were used as variables in the analysis. In a panel of ten members of ASEAN, multiple econometrics techniques for panel data analysis were used, including panel unit root test for data stationarity, panel cointegration test for long-run relationships, panel ARDL for the long-run and short-run dynamics, and finally DH Granger causality test for determining causal relationships among the variables [51].

\subsection{Empirical Models}

\subsubsection{Fiscal Causal Hypotheses Model for Sustainable Growth}

The first empirical model investigates the sustainable ratios of government expenditures and revenues towards economic growth. The model can be represented as follows:

$$
\begin{gathered}
\mathrm{GDP}_{i t}=\alpha_{\mathrm{i}}+\beta \mathrm{GEXP}_{\text {it }}+\gamma \mathrm{GREV}_{\text {it }}+\varepsilon_{\text {it }} \\
\mathrm{i}=1,2, \ldots, \mathrm{N} ; \mathrm{t}=1,2, \ldots, \mathrm{T}
\end{gathered}
$$

In Equation (1), i represents cross-sections (individuals) at time t. $\alpha_{i}$ represents the unobserved individual effect and time-invariant intercepts. The individual intercept $\alpha_{\mathrm{i}}$ is supposed to control the impact of an unobservable regressor specific to individual $i$. GEXP $_{\text {it }}$ and GREV $_{\text {it }}$ indicate the explanatory variable of individual $i$ at time t. $\beta, \gamma$ implies a vector of regression coefficients and $\varepsilon_{i t}$ shows the error term of individual $i$ at time $t$.

\subsubsection{Panel Twin Deficit Model}

The causal relationship between CAD and FD is to be examined. For this purpose, we proposed a framework based on the Keynesian macroeconomic model, i.e., the MundellFleming model (under flexible exchange rate). The Mundell-Fleming model explains money supply, fiscal and trade policies to achieve economic objectives. The model states that the real domestic interest rate becomes high due to increased fiscal deficit, which attracts foreign capital inflows and appreciation in domestic currency, leading to CAD (Current Account Deficit). The Mundell-Fleming model was utilized by a previous study investigating the dynamics of Thailand's fiscal and current account deficits [52]. We investigate the relationship in a four-factor CAD function. The empirical model for panel twin deficit estimation is presented as follows:

$$
\mathrm{CAD}_{\mathrm{it}}=\alpha_{\mathrm{o}}+\alpha_{1 \mathrm{i}} \sum_{\mathrm{k}=1}^{\mathrm{K}} \mathrm{FD}_{\mathrm{t}-\mathrm{k}}+\alpha_{2 \mathrm{i}} \sum_{\mathrm{k}=1}^{\mathrm{K}} \mathrm{EXC}_{\mathrm{t}-\mathrm{k}}+\alpha_{3 \mathrm{i}} \sum_{\mathrm{k}=1}^{\mathrm{K}} \mathrm{IR}_{\mathrm{t}-\mathrm{k}}+\alpha_{4 \mathrm{i}} \sum \mathrm{GDPi}+\varepsilon_{\mathrm{it}}
$$

$\mathrm{i}=1,2, \ldots, 10$ refers to the individual dimension, and $\mathrm{t}=1,2, \ldots, 30$ denotes the time dimension. $\varepsilon_{i t}$ reflects the error term of individual $i$ at time $t$.

\subsubsection{Panel Fiscal Deficit and Inflation Model}

This study presents the amended version of the fiscal deficit and inflation relationship. This amended version includes sources of finance for the fiscal deficit in ASEAN. First, to deal with inflation, this study uses the consumer price index, which is an alternate inflation variable. According to macroeconomic theory, a fiscal deficit can be inflationary; in other 
words, inflation is a function of the fiscal deficit discussed in [53,54]. The government authorities can finance the deficit in different sources, such as external and domestic borrowing and money supply. Thus, this study uses money supply as an endogenous variable and debt outstanding of ASEAN, which represents both domestic and external borrowing. In the model (Equation (3)), inflation is utilized as a function of fiscal deficit, as suggested in a previous study [53]. The GDP is considered as a control variable, and the money supply (M2) is used as an endogenous variable, one of the sources of finance for the fiscal deficit as a central bank tool. The connection between inflation and fiscal deficit is expressed as below:

$$
\mathrm{CPI}_{\mathrm{it}}=\alpha_{0}+\beta_{1 \mathrm{i}} \sum_{\mathrm{k}=1}^{\mathrm{K}} \mathrm{FD}_{\mathrm{t}-\mathrm{k}}+\beta_{2 \mathrm{i}} \sum_{\mathrm{k}=1}^{\mathrm{K}} \mathrm{GDP}_{\mathrm{t}-\mathrm{k}}+\beta_{3 \mathrm{i}} \sum_{\mathrm{k}=1}^{\mathrm{K}} \mathrm{M} 2_{\mathrm{t}-\mathrm{k}}+\varepsilon_{\mathrm{it}}
$$

The model (Equation (3)) reflects the direct effect of fiscal deficit on inflation. It is revised by substituting the FD with its source of financing, that is, debt outstanding, and thus represents the model (Equation (4)). Debt outstanding contains all sources of debt, such as domestic debt and external debt. Additionally, political stability (PS) is introduced in this model as a moderator between inflation and the source of finance to explicitly examine the significance of the PS as a moderating variable. The revised model is expressed as follows:

$$
\mathrm{CPI}_{\mathrm{it}}=\alpha_{0}+\beta_{1 \mathrm{i}} \sum_{\mathrm{k}=1}^{\mathrm{K}} \mathrm{DST}_{\mathrm{t}-\mathrm{k}}+\beta_{2 \mathrm{i}} \sum_{\mathrm{k}=1}^{\mathrm{K}} \mathrm{PS}_{\mathrm{t}-\mathrm{k}}+\beta_{3 \mathrm{i}} \sum_{\mathrm{k}=1}^{\mathrm{K}} \mathrm{M} 2_{\mathrm{t}-\mathrm{k}}+\beta_{4 \mathrm{i}} \sum_{\mathrm{k}=1}^{\mathrm{K}} \mathrm{GDP}_{\mathrm{t}-\mathrm{k}}+\varepsilon_{\mathrm{it}}
$$

\subsection{Econometric Techniques \\ 3.3.1. Unit Root Testing}

Previous empirical analyses reported that unit root for time series analysis could not work well for short-run time span [55-57]. However, panel unit root tests have a higher power in a panel data structure than unit root tests based on time series. The most efficient tests for stationarity in panel data setup, empirically tested by Baltagi [58], were those developed by Levin, Lin, and Chu or LLC [57] and Im, Pesaran, and Shin or IPS [56]. Therefore, this study employed a panel unit root test introduced by LLC and IPS. Order of integration needs to be investigated before moving forward to cointegration relationships. Levin, Lin, and Chu (LLC) contended that individual unit roots have limited power against alternative hypotheses with persistent deviation from the equilibrium. On the contrary, IPS assumes individual unit root processes, and unit root coefficients may differ across individuals.

\subsubsection{Panel Auto-Regressive Distributed Lag (ARDL) Model}

One of the limitations of the cointegration test is that it does not explains the shortrun and long-run dynamics. Therefore, to cover this limitation of the cointegration test and evaluate long-term and short-term significance, the panel ARDL was used [59]. The panel ARDL is based on Pooled Mean Group (PMG). According to Pesaran et al. [60], the homogeneity in long-run relationships appears due to numerous aspects, such as traditional technologies and mutual institutional development. The panel ARDL method avoids those deficiencies that can arise due to the classification of tested variables following integration order I(0) and I(1). Furthermore, ARDL is suitable for the endogeneity issue of independent variables [61]. The panel ARDL based on PMG can alleviate endogeneity by including sufficient lags of all variables, as suggested by Pesaran et al. [60]. The autoregressive distributed lag model works well as compared to conventional panel cointegration tests. Likewise, it is beneficial to investigate long-run and short-run variations. The panel ARDL models are given as follows: 


$$
\Delta \mathrm{GDP}_{\mathrm{it}}=\alpha_{\mathrm{i}}+\beta_{1} \sum_{\mathrm{k}=1}^{\mathrm{K}} \mathrm{GE}_{\mathrm{it}}+\beta_{2} \sum_{\mathrm{k}=1}^{\mathrm{K}} \mathrm{GR}_{\mathrm{it}}+\delta_{1 \mathrm{i}} \sum_{\mathrm{k}=1}^{\mathrm{K}} \Delta \mathrm{GE}_{\mathrm{i}, \mathrm{t}-\mathrm{k}}+\delta_{2 \mathrm{i}} \sum_{\mathrm{k}=1}^{\mathrm{K}} \Delta \mathrm{GR}_{\mathrm{i}, \mathrm{t}-\mathrm{k}}+\delta_{3 \mathrm{i}} \sum_{\mathrm{k}=1}^{\mathrm{K}} \Delta \mathrm{GDP}_{\mathrm{i}, \mathrm{t}-\mathrm{k}}+\varepsilon_{\mathrm{it}}
$$

GDP represents the gross domestic product, GE and GR represent the variables "government expenditures" and "government revenues" in individual $i$ at time $t$ with lag k. $\alpha_{i}$ denotes the country's specific intercept.

Long-run dynamics for panel ARDL model are labeled as follows:

$$
\mathrm{GDP}_{\mathrm{it}}=\mu_{\mathrm{i}}+\sum_{\mathrm{k}=0}^{\mathrm{K}} \delta_{1 \mathrm{i}} \Delta \mathrm{GE}_{\mathrm{i}, \mathrm{t}-\mathrm{k}}+\sum_{\mathrm{i}=0}^{\mathrm{n}} \delta_{2 \mathrm{i}} \Delta \mathrm{GR}_{\mathrm{i}, \mathrm{t}-\mathrm{k}}+\varepsilon_{\mathrm{it}}
$$

The pooled mean group method has been employed as a supposition that long-run coefficients are analogous for each individual $\mathrm{i}$. In the long-run equation, coefficients $\delta_{1 \mathrm{i}}$ and $\delta_{2 i}$ convey the sustainability ratios of GE and GR, respectively. These ratios indicate the contribution of GE and GR towards economic growth and also differentiate weak and robust fiscal sustainable growth, as reported by $[62,63]$. If ratios $\delta_{1 \mathrm{i}}$ and $\delta_{2 \mathrm{i}}$ approach unity, then there is high sustainable growth. In another case, $\delta_{1 \mathrm{i}}$ and $\delta_{2 \mathrm{i}}$ diverge from unity or giving negative value indicates a low level of sustainable growth. The short-run variations expressed by the error correction model are defined as follows:

$$
\Delta \mathrm{GDP}_{\mathrm{it}}=\alpha_{\mathrm{i}}+\sum_{\mathrm{k}=0}^{\mathrm{K}} \delta_{1 \mathrm{i}} \Delta \mathrm{GE}_{\mathrm{i}, \mathrm{t}-\mathrm{k}}+\sum_{\mathrm{k}=0}^{\mathrm{K}} \delta_{2 \mathrm{i}} \Delta \mathrm{GR}_{\mathrm{i}, \mathrm{t}-\mathrm{k}}+\sum_{\mathrm{k}=0}^{\mathrm{K}} \delta_{3 \mathrm{i}} \Delta \mathrm{GDP}_{\mathrm{i}, \mathrm{t}-\mathrm{k}}+\alpha \mathrm{ECT}_{\mathrm{t}-1}+\varepsilon_{\mathrm{i}, \mathrm{t}}
$$

PMG estimators are typically distributed and consistent, as explained by Baltagi [58]. The model's residual $\varepsilon_{i, t}$ is scattered independently and usually with zero mean and constant variance, and the ECT term represents the error correction term estimated from the long-run equilibrium. Its coefficient measures the speed of adjustment to the equilibrium level.

The panel ARDL for the empirical model (Equation (2)) needs to be analyzed for the bound test method, presented as follows:

$$
\begin{gathered}
\Delta \mathrm{CAD}_{\mathrm{it}}=\beta_{\mathrm{o}}+\beta_{1 \mathrm{i}} \sum_{\mathrm{k}=1}^{\mathrm{K}} \Delta \mathrm{FD}_{\mathrm{t}-\mathrm{k}}+\beta_{2 \mathrm{i}} \sum_{\mathrm{GDP}}+\beta_{3 \mathrm{i}} \sum_{\mathrm{k}=1}^{\mathrm{K}} \Delta \mathrm{EXC} \mathrm{C}_{\mathrm{t}-\mathrm{k}}+\beta_{4 \mathrm{i}} \sum_{\mathrm{k}=1}^{\mathrm{K}} \Delta \mathrm{IR}_{\mathrm{t}-\mathrm{k}}+\theta_{1} \mathrm{FD}_{\mathrm{t}-1}+\theta_{2} \mathrm{GDP}_{\mathrm{i}} \\
+\theta_{3} \mathrm{EXC}_{\mathrm{t}-1}+\theta_{4} \mathrm{IR}_{\mathrm{t}-1}+\varepsilon_{\mathrm{it}}
\end{gathered}
$$

$\mathrm{k}=1,2, \ldots, \mathrm{K}$ presents the number of lags. $\mathrm{i}=1,2, \ldots, 10$ refers to the individual dimension, and $t=1,2, \ldots, 30$ denotes the time dimension. $\varepsilon_{\text {it }}$ represents the error term of individual $i$ at time $t$. We utilized the panel autoregressive distributed lag bounds test. If there is proof of a long-run relation, then long-run and short equations, Equations (9) and (10), are estimated simultaneously based on pool mean group (PMG).

$$
\begin{array}{r}
\mathrm{CAD}_{\mathrm{it}}=\alpha_{\mathrm{o}}+\alpha_{1 \mathrm{i}} \sum_{\mathrm{k}=1}^{\mathrm{K}} \mathrm{FD}_{\mathrm{t}-\mathrm{k}}+\alpha_{2 \mathrm{i}} \sum_{\mathrm{k}=1}^{\mathrm{K}} \mathrm{EXC}_{\mathrm{t}-\mathrm{k}}+\alpha_{3 \mathrm{i}} \sum_{\mathrm{k}=1}^{\mathrm{K}} \mathrm{IR}_{\mathrm{t}-\mathrm{k}}+\varepsilon_{\mathrm{it}} \\
\Delta \mathrm{CAD}_{\mathrm{it}}=\beta_{\mathrm{o}}+\beta_{1 \mathrm{i}} \sum_{\mathrm{k}=1}^{\mathrm{K}} \Delta \mathrm{FD}_{\mathrm{t}-\mathrm{k}}+\beta_{2 \mathrm{i}} \sum_{\mathrm{GDP}}+\beta_{3 \mathrm{i}} \sum_{\mathrm{k}=1}^{\mathrm{K}} \Delta \mathrm{EXC}_{\mathrm{t}-\mathrm{k}}+\beta_{4 \mathrm{i}} \sum_{\mathrm{k}=1}^{\mathrm{K}} \Delta \mathrm{IR}_{\mathrm{t}-\mathrm{k}}+v \mathrm{ECT}_{\mathrm{it}}+\varepsilon_{\mathrm{it}}
\end{array}
$$

Equation (9) refers to the long-run relationship. $\alpha_{1 \mathrm{i}}$ is the coefficient value between CAD and FD at periods $t$ and $t-k$. Similarly, $\alpha_{2 i}$ and $\alpha_{3 i}$ present the coefficient value of EXC and IR. The $\alpha_{4 i}$ presents the coefficient value of GDP, which is exogenously affecting CAD. Similarly, Equation (10) refers to the short-run dynamics. $\beta_{0}, \beta_{1 i}, \beta_{2 i}, \beta_{3 i}$ and $\beta_{4 \mathrm{i}}$ indicate the coefficient values of differenced tested variables for short-run dynamics. The coefficient $v$ points ECT (error correction term). The ECT coefficient validates the adjustment towards equilibrium. 
For fiscal deficit and inflation, this study presents two modified models for the relationship of fiscal deficit and inflation. The model in Equation (3), where inflation is a function of fiscal deficit (FD), money supply (M2), and GDP, its panel ARDL for the bound test method, is presented as follows:

$$
\Delta C I_{i t}=\beta_{\mathrm{o}}+\beta_{1 \mathrm{i}} \sum_{\mathrm{k}=1}^{\mathrm{K}} \mathrm{FD}_{\mathrm{t}-\mathrm{k}}+\beta_{2 \mathrm{i}} \sum_{\mathrm{k}=1}^{\mathrm{K}} \mathrm{GDP}_{\mathrm{t}-\mathrm{k}}+\beta_{3 \mathrm{i}} \sum_{\mathrm{k}=1}^{\mathrm{K}} \Delta \mathrm{M} 2_{\mathrm{t}-\mathrm{k}}+\theta_{1} \mathrm{FD}_{\mathrm{t}-1}+\theta_{2} \mathrm{GDP}_{\mathrm{t}-1}+\theta_{3} \mathrm{M}_{\mathrm{t}-1}+\varepsilon_{\mathrm{it}}
$$

Its long-run and short-run equations are defined as follows:

$$
\begin{gathered}
\mathrm{CPI}_{\mathrm{it}}=\alpha_{\mathrm{o}}+\alpha_{1 \mathrm{i}} \sum_{\mathrm{k}=1}^{\mathrm{K}} \mathrm{FD}_{\mathrm{t}-\mathrm{k}}+\alpha_{2 \mathrm{i}} \sum_{\mathrm{k}=1}^{\mathrm{K}} \mathrm{M} 2_{\mathrm{t}-\mathrm{k}}+\alpha_{3 \mathrm{i}} \sum_{\mathrm{k}=1}^{\mathrm{K}} \mathrm{GDP}_{\mathrm{t}-\mathrm{k}}+\varepsilon_{\mathrm{it}} \\
\Delta \mathrm{CPI}_{\mathrm{it}}=\beta_{\mathrm{o}}+\beta_{1 \mathrm{i}} \sum_{\mathrm{k}=1}^{\mathrm{K}} \Delta \mathrm{FD}_{\mathrm{t}-\mathrm{k}}+\beta_{2 \mathrm{i}} \sum_{\mathrm{k}=1}^{\mathrm{K}} \Delta \mathrm{GDP}_{\mathrm{t}-\mathrm{k}}+\beta_{3 \mathrm{i}} \sum_{\mathrm{k}=1}^{\mathrm{K}} \Delta \mathrm{M} 2_{\mathrm{t}-\mathrm{k}}+\nu \mathrm{ECT}_{\mathrm{it}}+\varepsilon_{\mathrm{it}}
\end{gathered}
$$

In the above panel ARDL, Equations (12) and (13) present the long-run and short-run dynamics, respectively. $k=1,2, \ldots, K$ presents the number of lags. $i=1,2, \ldots, 10$ refers to the individual dimension, and $\mathrm{t}=1,2, \ldots, 30$ denotes the time dimension. $\varepsilon_{\mathrm{it}}$ represents the error term of individual $i$ at time $t$.

The model (Equation (4)) of fiscal deficit and inflation introduced debt outstanding in place of fiscal deficit and political stability as a moderator between sources of financing and inflation. Thus, the panel ARDL for model (Equation (4)) is given below.

$$
\begin{gathered}
\Delta \mathrm{CPI}_{\mathrm{it}}=\beta_{\mathrm{o}}+\beta_{1 i} \sum_{\mathrm{k}=1}^{\mathrm{K}} \mathrm{DST}_{\mathrm{t}-\mathrm{k}}+\beta_{2 i} \sum_{\mathrm{k}=1}^{\mathrm{K}} \mathrm{PS}_{\mathrm{t}-\mathrm{k}}+\beta_{4 \mathrm{i}} \sum_{\mathrm{k}=1}^{\mathrm{K}} \Delta \mathrm{M} 2_{\mathrm{t}-\mathrm{k}}+\beta_{3 \mathrm{i}} \sum_{\mathrm{k}=1}^{\mathrm{K}} \mathrm{GDP}_{\mathrm{t}-\mathrm{k}}+\theta_{1} \mathrm{DST}_{\mathrm{t}-1}+\theta_{2} \mathrm{PS}_{\mathrm{t}-1}+\theta_{3} \mathrm{GDP}_{\mathrm{t}-1} \\
+\theta_{4} \mathrm{M} 2_{\mathrm{t}-1}+\varepsilon_{\mathrm{it}}
\end{gathered}
$$

The corresponding long-run and short-run equations of panel ARDL (Equation (14)) are shown as follows:

$$
\begin{array}{r}
\mathrm{CPI}_{\mathrm{it}}=\alpha_{\mathrm{o}}+\alpha_{1 \mathrm{i}} \sum_{\mathrm{k}=1}^{\mathrm{K}} \mathrm{DST}_{\mathrm{t}-\mathrm{k}}+\alpha_{2 \mathrm{i}} \sum_{\mathrm{k}=1}^{\mathrm{K}} \mathrm{M} 2_{\mathrm{t}-\mathrm{k}}+\alpha_{3 \mathrm{i}} \sum_{\mathrm{k}=1}^{\mathrm{K}} \mathrm{GDP}_{\mathrm{t}-\mathrm{k}}+\varepsilon_{\mathrm{it}} \\
\Delta \mathrm{CPI} \mathrm{I}_{\mathrm{it}}=\beta_{\mathrm{o}}+\beta_{1 \mathrm{i}} \sum_{\mathrm{k}=1}^{\mathrm{K}} \Delta \mathrm{DST}_{\mathrm{t}-\mathrm{k}}+\beta_{2 \mathrm{i}} \sum \mathrm{PSi}+\beta_{3 \mathrm{i}} \sum_{\mathrm{k}=1}^{\mathrm{K}} \Delta \mathrm{GDP}_{\mathrm{t}-\mathrm{k}}+\beta_{4 \mathrm{i}} \sum_{\mathrm{k}=1}^{\mathrm{K}} \Delta \mathrm{M} 2_{\mathrm{t}-\mathrm{k}}+v \mathrm{ECT}_{\mathrm{it}}+\varepsilon_{\mathrm{it}}
\end{array}
$$

\subsubsection{Panel DH Granger Causality Test}

The econometrics techniques discussed in previous sections are used for data stationarity and cointegration. Now, in this section, fiscal causal and twin deficit hypotheses are estimated. Gkillas and colleagues [64] proposed a nonlinear granger causality model with a nonparametric approach. The nonlinear causality approach could be helpful with highly dynamic data, for example, dynamic frequency variance. However, this study adopted the extended form of linear Granger causality technique, the DH causality [51], with a parametric approach, based on the nature of data and recommendation of a linear relationship in previous studies [51,65]. The DH technique presents causality among the panel variables. This test provides more information relative to other techniques; for instance, it is suitable for unbalanced panel data and cross-sectional dependence among individual panel members. It considers two estimations: the heterogeneous nature of the regression model and the heterogeneous nature of the causal association. The DH granger causality assumes a standard adjusted Wald test for individuals observed in each period. The DH test assumes that adjusted Wald is asymptotically good and can be employed to examine panel causality. Additionally, under this supposition, Wald statistics are identical and independently distributed across individuals [65]. Equations (17) and (18) reflect the 
fiscal causal hypotheses for the investigation of causal associations between government expenditures (GEs) and government revenues (GRs). Moreover, adding GDP as an exogenous variable eliminates the problematic spurious causal properties due to the omission of significant variables from the examined association [66].

$$
\begin{gathered}
\mathrm{GE}_{\mathrm{i}, \mathrm{t}}=\alpha_{\mathrm{i}}+\gamma_{1 \mathrm{i}} \sum_{\mathrm{k}=1}^{\mathrm{K}} \mathrm{GE}_{\mathrm{i}, \mathrm{t}-\mathrm{k}}+\gamma_{2 \mathrm{i}} \sum_{\mathrm{k}=1}^{\mathrm{K}} \mathrm{GR}_{\mathrm{i}, \mathrm{t}-\mathrm{k}}+\gamma_{3 i} \sum_{\mathrm{k}=1}^{\mathrm{K}} \mathrm{GDP}_{\mathrm{i}, \mathrm{t}-\mathrm{k}}+\varepsilon_{\mathrm{i}, \mathrm{t}} \\
\mathrm{GR}_{\mathrm{i}, \mathrm{t}}=\alpha_{\mathrm{i}}+\gamma_{4 \mathrm{i}} \sum_{\mathrm{k}=1}^{\mathrm{K}} \mathrm{GR}_{\mathrm{i}, \mathrm{t}-\mathrm{k}}+\gamma_{5 i} \sum_{\mathrm{k}=1}^{\mathrm{K}} \mathrm{GE}_{\mathrm{i}, \mathrm{t}-\mathrm{k}}+\gamma_{6 \mathrm{i}} \sum_{\mathrm{k}=1}^{\mathrm{K}} \mathrm{GDP}_{\mathrm{i}, \mathrm{t}-\mathrm{k}}+\varepsilon_{\mathrm{i}, \mathrm{t}} \\
\mathrm{i}=1,2, \ldots, \mathrm{N}: \mathrm{t}=1,2, \ldots, \mathrm{T}, \mathrm{k}=\mathrm{lag}
\end{gathered}
$$

In addition, Equations (19)-(22), reflect the relationships of the current account deficit (CAD), fiscal deficit (FD), the exchange rate (EXC), and interest rate (IR), as given below:

$$
\begin{aligned}
& \operatorname{CAD}_{i t}=\alpha_{i}+\beta_{1 i} \sum_{j=1}^{k} \operatorname{FD}_{t-j}+\beta_{2 i} \sum_{j=1}^{k} \operatorname{EXC}_{t-j}+\beta_{3 i} \sum_{j=1}^{k} I_{t-j}+\mu_{i t} \\
& \mathrm{FD}_{i t}=\alpha_{i}+\beta_{4 i} \sum_{j=1}^{k} \operatorname{CAD}_{t-j}+\beta_{5 i} \sum_{j=1}^{k} \operatorname{EXC}_{t-j}+\beta_{6 i} \sum_{j=1}^{k} I_{t-j}+\mu_{i t} \\
& \operatorname{EXC}_{i t}=\alpha_{i}+\gamma_{1 i} \sum_{j=1}^{k} \operatorname{CAD}_{t-j}+\gamma_{2 i} \sum_{j=1}^{k} \operatorname{FD}_{t-j}+\gamma_{3 i} \sum_{j=1}^{k} I_{t-j}+\mu_{i t} \\
& \operatorname{IR}_{i t}=\alpha_{i}+\gamma_{1 i} \sum_{j=1}^{k} \operatorname{CAD}_{t-j}+\gamma_{2 i} \sum_{j=1}^{k} \operatorname{FD}_{t-j}+\gamma_{3 i} \sum_{j=1}^{k} E X C_{t-j}+\mu_{i t} \\
& i=1,2, \ldots, 10 ; t=1,2, \ldots, 30 ;=1,2, \ldots, k ; N=10 ; T=30
\end{aligned}
$$

We assumed that all tested variables are stationary and observed for $\mathrm{N}$ individuals in the " $\mathrm{t}$ " period. Lag order $\mathrm{k}$ is meant to be identical for all cross-sections in the panel. $\gamma_{1}, \gamma_{2}$ and $\gamma_{3}$ can vary across individuals. The null hypothesis is that "there is no causal relationship" known as homogeneous noncausality (HNC). Here, we have two alternate hypotheses: the first alternative hypothesis states that there is a heterogeneous causal relationship but not in all individuals, and the second alternative hypothesis indicates that there is causality in all individuals.

$$
\begin{array}{ll}
\mathrm{H}_{0}=\gamma_{1 \mathrm{i}}=\gamma_{2 \mathrm{i}}=\gamma_{3 \mathrm{i}}=0 & \forall \mathrm{i}=1,2, \ldots, \mathrm{N} \\
\mathrm{H}_{\mathrm{A} 1}=\gamma_{1 \mathrm{i}}=\gamma_{2 \mathrm{i}}=\gamma_{3 \mathrm{i}}=0 & \mathrm{i}=1,2, \ldots, \mathrm{N}_{1}, \mathrm{~N}_{1}<\mathrm{N} \\
\mathrm{H}_{\mathrm{A} 2}=\gamma_{1 \mathrm{i}} \neq \gamma_{2 \mathrm{i}} \neq \gamma_{3 \mathrm{i}} \neq 0 & \mathrm{i}=\mathrm{N}_{1}+1, \mathrm{~N}_{1}+2, \ldots, \mathrm{N}
\end{array}
$$

\section{Empirical Findings and Discussion}

This study analyzes the fiscal causal, twin deficit hypothesis, and fiscal-inflation relationship to disclose whether the fiscal deficit of ASEAN is alarming or not. For this purpose, this panel study utilized panel unit root tests for all tested variables. Next, panel ARDL is employed in three stages: the first stage contains panel ARDL for fiscal causal hypotheses, the second stage includes panel ARDL for twin deficit hypotheses, and the third stage uses panel ARDL for fiscal deficit and inflation. After panel ARDL, this study utilized the DH granger causality test in two stages, the first stage is for the fiscal causal relationship and the second stage is for twin deficit hypotheses.

\subsection{Panel Unit Root Testing for Tested Variables}

At the start of the analysis, the data need to be stationary. Two kinds of panel unit root tests are applied for checking stationarity. One test is known as Im, Pesaran, shin (IPS), which is used for the individual unit root (cross-section) and the other is Levin, Lin and $\mathrm{Chu}$, which is used for common unit root. The Akaike information criterion (AIC) is 
adopted to determine the number of lags, which effectively avoids autoregression with higher lag order. At the first difference, the variables GE, GR, CAD, FD, GDP, DST, and EXC are stationary, while at a level with intercept, the variables IR, CPI, M2, and PS are stationary; the trend is listed in Table 1.

Table 1. Panel unit root results.

\begin{tabular}{ccccc}
\hline \multirow{2}{*}{ All Tested Variables } & \multicolumn{2}{c}{ Levin, Lin and Chu (LLC) } & \multicolumn{2}{c}{ Im, Pesaran, Shin (IPS) } \\
\cline { 2 - 5 } & Level & First Difference & Level & First Difference \\
\hline GDP & {$[2.44](0.89)$} & {$[6.48](0.001)^{* * *}$} & {$[5.56](0.99)$} & {$[73.71](0.00)^{* * * *}$} \\
GR & {$[1.49](093)$} & {$[7.86](0.00)^{* * *}$} & {$[15.78](0.72)$} & {$[95.88](0.00)^{* * *}$} \\
GE & {$[3.16](0.99)$} & {$[6.40](0.00)^{* * *}$} & {$[2.35](0.99)$} & {$[76.88](0.00)^{* * *}$} \\
CAD & {$[-1.39](0.11)$} & {$[-7.45](0.00)^{* * *}$} & {$[-0.88](0.18)$} & {$[-7.85](0.00)^{* * *}$} \\
FD & {$[0.008](0.50)$} & {$[-5.24](0.00)^{* * *}$} & {$[-1.11](0.13)$} & {$[-6.30](0.00)^{* * *}$} \\
EXC & {$[-0.10](0.45)$} & {$[-3.70](0.00)^{* * *}$} & {$[0.90](0.81)$} & {$[-2.50](0.00)^{* * *}$} \\
IR & {$[2.82](0.00)^{* * *}$} & - & {$[-5.62](0.00)^{* * *}$} & - \\
CPI & {$[-3.46](0.00)^{* * *}$} & - & {$[-3.16](0.00)^{* * *}$} & - \\
M2 & {$[-2.19](0.01)^{* *}$} & - & {$[-2.57](0.00)^{* * *}$} & - \\
DST & {$[-0.38](0.34)$} & $-5.56(0.00)^{* * *}$ & {$[0.31](0.62)$} & {$[-3.87](0.00)^{* * *}$} \\
PS & {$[-2.21](0.01)^{* *}$} & - & {$[-1.95](0.02)$} & - \\
\hline
\end{tabular}

Note: ${ }^{* * *}, * *$ representing significance at $1 \%$ and $5 \%$, respectively; value in parenthesis brackets presents $p$-values. Square brackets indicate $t$-statistic values.

\subsection{Findings of Panel $A R D L$}

This section presents the panel ARDL findings for the three stages, i.e., the first stage of panel ARDL is about fiscal causal hypotheses, the second stage of panel ARDL is about twin deficit hypotheses, and finally, the third stage is about the fiscal deficit, deficit financing, and inflation.

The panel ARDL model selection used the Akaike information criterion (AIC), covering automatic lag selection (four lags). In a long-run assessment, in Table 2, government expenditures (GEs) show a long-term relationship with GDP, and GE has a positive and statistically significant influence on GDP. Simultaneously, an inverse relationship of GR with GDP is observed, which means that maximizing revenue may not result in maximum growth in the long run. Thus, government revenue is proved to be not significant in the long run. After analyzing the significance of variables in the long run, sustainable ratios are estimated in long-run analysis, which can classify weak and robust sustainable growth, as Quintos [62] proposed. The coefficients $\delta_{1 \mathrm{i}}$ and $\delta_{2 \mathrm{i}}$ represent the long-run sensitivities of GE and GR, respectively. The $\delta_{1 \mathrm{i}}$ value is 0.8997 , which is close to unity, indicating a strong contribution from the expenditures side towards sustainable growth. The $\delta_{2 i}$ value is -0.0048 , which is relatively low and expresses a weak influence of revenues towards sustainable growth (see Table 2). A strong sustainability ratio is desired for sustainable economic growth. A weak ratio can also be considered satisfied; as reported previously [67], government authorities can face difficult times maintaining sustainability if expenditures sensitivity is continuously increasing compared to revenues.

This study disclosed the fact that GE contributes more towards economic growth These results are robust, compared to those of Keynesian's approach. One of the criticisms of this approach is that to increase government expenditures (expansionary fiscal policy), authorities borrow money, which exerts upward pressures on the interest rate and may discourage private investors in the long run. This phenomenon is called crowding out, and it reduces the impacts of fiscal policy. On the contrary, neoclassical methods result in low taxation and limited government expenditures. Accordingly, low taxation can minimize the cost of production with stable prices and promote economic growth. Keynesian argued that crowding out is temporary and can be partial as the economy does not fully operate. In this study, government revenues are inversely related to economic growth in the long run, which reflects that high taxation makes the taxpayer more aggressive towards government spending by lowering their quantity demands and creating a substitution effect. 
Table 2. Results of ARDL for government expenditures and revenues.

\begin{tabular}{ccccc}
\hline & Coefficient & Standard Error & \multicolumn{1}{c}{$\boldsymbol{t}$-Statistic } & Prob. \\
\hline \multicolumn{5}{c}{ Long-run estimation } \\
\hline GR & -0.004 & 0.006 & -0.709 & 0.48 \\
\hline GE & 0.87 & 0.020 & 41.41 & $0.002^{*}$ \\
\hline ECT & \multicolumn{4}{c}{ Short-run estimation } \\
$\Delta$ GE & -0.136 & 0.105 & -1.294 & 0.19 \\
$\Delta$ GE $(-1)$ & 0.570 & 0.153 & 3.709 & $0.000^{*}$ \\
$\Delta$ GE $(-2)$ & -0.093 & 0.102 & -0.911 & 0.36 \\
$\Delta$ GE $(-3)$ & -0.140 & 0.081 & -1.724 & $0.08^{*}$ \\
$\Delta$ GR & -0.048 & 0.070 & -0.694 & 0.48 \\
$\Delta$ GR $(-1)$ & 0.250 & 0.140 & 1.784 & $0.07 *$ \\
$\Delta$ GR $(-2)$ & 0.033 & 0.110 & 0.299 & 0.76 \\
$\Delta$ GR $(-3)$ & -0.009 & 0.159 & -0.059 & 0.95 \\
$\Delta$ GDP $(-1)$ & 0.293 & 0.119 & 2.462 & 0.01 \\
C & 0.183 & 0.125 & 1.462 & 0.14 \\
\hline
\end{tabular}

Note: $\mathrm{C}$ is constant/intercept and * denotes significance.

One of the advantages of utilizing panel ARDL is the short-run analysis which estimates short-run dynamics and expresses the consistent error correction term (ECT) with long-run equilibrium. The ECT provides the adjustment and restoration when there is a deviation from long-run equilibrium. It is reported that a negative ECT with a range of 0 to 1 is sufficient for a stable error correction mechanism [68]. In Table 2, ECT is -0.13 , indicating 13 percent annual convergence to the long-run equilibrium. The short-run dynamics were measured by automatic lag selection (four lags) and it was found that GR is impactful as $\Delta \mathrm{GR}$ and $\Delta \mathrm{GR}(-3)$ are statistically significant and positively associated with GDP. Furthermore, government expenditures $\Delta \mathrm{GE}$ and $\Delta \mathrm{GE}(-2)$ are significant.

The panel ARDL technique can analyze the long-run and short-run fluctuations. As far as the long-run equation is concerned, the results reveal that fiscal deficit (FD) has positive signs and is statistically significant-see Table 3 . This implies that the level of fiscal deficit is associated with the level of the current account deficit. A 1\% increase in FD can lead to generating (approx.) $6 \%$ in CAD. Fiscal deficit can influence CAD in many ways, and its most known channel is through the exchange rate and interest rate. The EXC is statistically significant and has a positive correlation with CAD. These results are in line with Mundell Fleming's views. Similarly, RIR has a positive relationship with CAD, which reveals that when the interest rate is high, capital inflows are encouraged, and the exchange rate appreciates, which leads to increased imports and generates a current account deficit (imports > exports). 
Table 3. Results of ARDL for fiscal and current account deficits.

\begin{tabular}{ccccc}
\hline $\begin{array}{c}\text { Dependent Variable } \\
\text { CAD }\end{array}$ & Coefficient & Standard Error & t-Statistic & Prob. \\
\hline FD & \multicolumn{4}{c}{ Long-run dynamics } \\
\hline EXC & 0.0636 & 0.0117 & 5.4175 & $0.0000^{* * *}$ \\
RIR & 0.00019 & $5.06 \times 10^{-5}$ & 3.9272 & $0.0002^{* * *}$ \\
& 0.0177 & 0.0133 & 1.3298 & 0.1867 \\
\hline ECT & & Short-run dynamics & \\
$\Delta($ CAD $(-1))$ & -0.81 & 0.16 & -5.06 & $0.00 * * *$ \\
$\Delta($ FD $)$ & 0.0119 & 0.1568 & 0.0761 & 0.9395 \\
$\Delta($ FD $(-1))$ & -0.0682 & 0.0489 & -1.3949 & 0.1662 \\
$\Delta($ EXC $)$ & -0.0402 & 0.0300 & -1.3386 & 0.1838 \\
$\Delta($ EXC $(-1))$ & 0.4384 & 0.3448 & 1.2715 & 0.2066 \\
$\Delta($ RIR $)$ & -0.1130 & 0.0825 & -1.3692 & 0.1741 \\
$\Delta($ RIR $(-1))$ & 0.0200 & 0.0321 & 0.6221 & 0.5353 \\
GDP & -0.0075 & 0.0193 & -0.3905 & 0.6970 \\
C & 0.8411 & 0.4469 & 1.8819 & $0.0628^{*}$ \\
\hline
\end{tabular}

Note: The model selection method is Akaike info criterion (AIC), GDP is used as a fixed regressor, model selection is ARDL (2 222 2). ${ }^{* * *},{ }^{*}$ represent significance at $1 \%$ and $10 \%$, respectively.

In short-run dynamics, model selection is ARDL $(2,2,2,2)$. The error correction term (ECT) is the most important element in the short-run analysis. It shows short-run adjustments to the long-run equilibrium. Here, ECT is -0.81 , which is highly significant. It reveals that $81 \%$ of convergence can be adjusted to long-run equilibrium annually. Remarkably, CAD is not significantly dependent on its previous year. FD is negatively related to CAD in short, but it is not statistically significant. Similarly, other factors such as RIR, EXC, and their lag values are not significant, showing no short-run relation tested variables. GDP acts like a fixed regressor (exogenous) and it is highly significant.

The Auto-Regressive Distributed Lag (ARDL) model is used to examine long-run and short-run fluctuations. The ARDL $(2,2,2,2)$ model is selected with auto-adjust. In Table 4 , the long-run equation is estimated with the dependent variable consumer price index as a proxy of inflation (CPI) and independent variables M, FD, and GDP. In model (Equation (3)), inflation is dependent on fiscal deficit, money supply, and GDP. Therefore, $\mathrm{M}, \mathrm{GDP}$, and FD are significant in the long run and statistically significant. The coefficient value of $\mathrm{M}$ is 0.19 , which indicates that one unit increase in money supply can bring 0.19 units in inflation; this change is less than unity, meaning that the money supply is not very sensitive to inflation. This result represents a positive relationship between money supply and inflation. According to monetary economics (Fisher quantity theory of money), if the real output remains the same and money supply increases, prices go up, and inflation occurs. However, if the real output increases along with the money supply, then inflation does not increase much. Further, if we observe a fiscal deficit, it has a significant impact on inflation, which supports the fiscal theory of price, i.e., an increase in fiscal deficit can affect the inflation rate. The GDP significantly affects the inflation rate. Remarkably, there is an inverse relationship between GDP and inflation, meaning that income is increasing and, on the other hand, the money supply is increasing but relatively less so than money demand. In this case, inflation decreases and GDP rises. Hence, $\mathrm{M}, \mathrm{FD}$, and GDP have a significant long-run relationship with inflation. As far as short-run relationships are concerned, the ECT is -0.91 , which indicates that 91 percent convergence to the long-run equilibrium is annually possible. The only factor GDP has a short-run relationship with inflation. 
Table 4. ARDL results for fiscal deficit and inflation.

\begin{tabular}{ccccc}
\hline $\begin{array}{c}\text { Dependent Variable } \\
\text { CPI }(\boldsymbol{\pi})\end{array}$ & Coefficient & Standard Error & t-Statistic & Prob. \\
\hline FD & \multicolumn{4}{c}{ Long-run Dynamics } \\
\hline M & 0.12 & 0.04 & 2.62 & $0.01^{* *}$ \\
GDP & 0.19 & 0.02 & 6.66 & $0.00^{* * *}$ \\
& -2.19 & 0.36 & -6.02 & $0.00^{* * *}$ \\
\hline ECT & & Short-run Dynamics & \\
$\Delta($ CPI $(-1))$ & -0.91 & 0.28 & -3.25 & $0.00^{* * *}$ \\
$\Delta($ FD) & 0.09 & 0.19 & 0.49 & 0.62 \\
$\Delta($ FD $(-1))$ & 0.30 & 0.18 & 1.61 & 0.10 \\
$\Delta(\mathrm{M})$ & 0.74 & 0.64 & 1.14 & 0.25 \\
$\Delta(\mathrm{M}(-1))$ & 0.45 & 0.35 & 1.27 & 0.20 \\
$\Delta(\mathrm{GDP})$ & 0.19 & 0.17 & 1.11 & 0.26 \\
$\Delta(\mathrm{GDP}(-1))$ & 39.56 & 9.45 & 4.18 & $0.00^{* * *}$ \\
$\mathrm{C}$ & 1.91 & 47.66 & 0.04 & 0.96 \\
\hline Note: ${ }^{* * *}, * *$ representing significance at $1 \%$ and $5 \%$, respectively. & 3.96 & $0.00^{* * *}$ \\
\hline
\end{tabular}

In the model (Equation (4)), inflation is dependent on money supply, government debt outstanding, political stability, and GDP. Therefore, the fiscal deficit is replaced with debt outstanding. The money supply and debt outstanding are two sources for financing the fiscal deficit. According to the Keynesian School of thought, budget deficits affect inflation through financing ways and means. In the long run (Equation (15)), the coefficient of debt outstanding (DST) is highly significant and impactful relative to the fiscal deficit, as shown in Table 5. One unit increase in DST can bring 4.33 units increase in inflation. The results show that DST is a strong source of fiscal deficit, which generates inflation. It should be taken into account that DST is sensitive to inflation as a source of financing the fiscal deficit. A large amount of DST can create hurdles for government authorities.

Table 5. ARDL results for Debt outstanding and inflation.

\begin{tabular}{ccccc}
\hline $\begin{array}{c}\text { Dependent Variable } \\
\text { CPI }(\boldsymbol{\pi})\end{array}$ & Coefficient & Standard Error & $\boldsymbol{t}$-Statistic & Prob. \\
\hline & \multicolumn{4}{c}{ Long-run Dynamics } \\
\hline DST & 4.33 & 1.04 & 4.15 & $0.00^{* * *}$ \\
M & 0.08 & 0.05 & 1.49 & 0.13 \\
GDP & -3.08 & 1.26 & -2.43 & $0.01^{* *}$ \\
\hline & \multicolumn{3}{c}{ Short-run Dynamics } \\
\hline ECT & -0.79 & 0.05 & -13.47 & $0.00^{* * *}$ \\
PS & -5.48 & 1.53 & -3.57 & $0.00^{* * *}$ \\
$\Delta(\mathrm{DST})$ & 25.60 & 27.49 & 0.93 & 0.35 \\
$\Delta(\mathrm{M})$ & 0.22 & 0.24 & 0.89 & 0.37 \\
$\Delta(\mathrm{GDP})$ & 20.14 & 12.59 & 1.59 & 0.11 \\
C & -5.96 & 3.68 & -1.61 &
\end{tabular}

When a government increases borrowing/debt to fill the gap between government expenditures and government revenues, it leads to an increased money supply in the market, generating inflation. The money supply turned insignificant by including the debt outstanding in the long-run equation, while GDP behavior is the same, as examined in Table 4 . In short-run dynamics, ECT is -0.79 , meaning 79 percent convergence is possible to the long-run equilibrium. The ARDL $(1,1,1,1)$ was selected with auto-adjust. PS (political stability) was included in the short-run equation as an exogenous variable. As it was 
having a collinearity problem with inflation in the long-run panel. It has been disclosed that political stability is impactful and significant in the short run. Political disturbance can generate inflation in the short run.

Furthermore, M, DST, and GDP are not significant in the short run. The modified fiscal deficit and inflation models showed that inflation can be the cause of fiscal deficit in ASEAN. Specifically, the debt outstanding of ASEAN is statistically significant and highly impactful towards inflation. To increase the level of government expenditures and to fill the gap of fiscal deficit, authorities raise borrowing, which leads to inflation from the source of financing. Here, a point to be noted is that by adding debt outstanding, the money supply is insignificant to inflation in Table 5, which means that money supply as a domestic source of financing the fiscal deficit is not influential towards inflation.

\subsection{Findings of Panel Dumitrescu Hurlin (DH) Test}

To measure the causality relationship between GE, GR, and GDP, the DH panel causality test was utilized with a lag length of 2 . In a causality relationship, it is necessary to avoid the problems of spurious causal effects which can arise due to the omission of a significant variable. For this purpose, GDP is included as a third variable in causality analysis because GE and GR are related to the overall economic growth. This study explores the causality between GR-GE, GR-GDP, and GE-GDP for a sustainable growth policy. Table 6 shows that government expenditures (GEs) cause government revenues (GRs) homogenously mean that the null hypothesis "does not cause" is rejected as the $\mathrm{W}$ and Zbar statistics are significant. Likewise, GR causes GE homogenously and rejects the null hypothesis as both statistic values are significant. Thus, the analysis illustrates a two-way or a bidirectional link between GR and GE. The bidirectional link between fiscal components indicates the policy implications of fiscal decisions that can be made simultaneously in ASEAN. As mentioned earlier, it is essential to consider the causal association between GR-GDP and GE-GDP for sustainable economic growth. Therefore, the analysis confirms that bidirectional causality occurs between GR-GDP and GE-GDP.

Table 6. Results of Dumitrescu Hurlin (DH) panel Granger causality.

\begin{tabular}{cccc}
\hline Null Hypotheses & Zbar-Statistics & W-Statistics & Prob. \\
\hline GE $\nrightarrow$ GR & 5.52 & 6.44 & $0.002^{*}$ \\
GR $\nrightarrow$ GE & 6.55 & 7.15 & $0.007^{*}$ \\
GDP $\nrightarrow$ GE & 12.29 & 11.42 & $0.002^{*}$ \\
GE $\nrightarrow$ GDP & 11.23 & 10.76 & $0.007^{*}$ \\
GDP $\nrightarrow$ GR & 7.23 & 7.77 & $0.001^{*}$ \\
GR $\nrightarrow$ GDP & 4.42 & 5.53 & $0.006^{*}$ \\
CAD $\nrightarrow$ FD & 2.33 & 4.56 & $0.01^{* * *}$ \\
FD $\nrightarrow$ CAD & -0.92 & 1.53 & 0.35 \\
FD $\nrightarrow$ EXC & -0.75 & 1.700 & 0.45 \\
EXC $\nrightarrow$ FD & -0.53 & 1.90 & 0.59 \\
EXC $\nrightarrow$ CAD & 0.77 & 3.12 & 0.43 \\
CAD $\nrightarrow$ EXC & 1.91 & 4.17 & $0.05^{* *}$ \\
FD $\nrightarrow$ IR & 0.004 & 2.40 & 0.99 \\
IR $\nrightarrow$ FD & 1.88 & 4.15 & $0.05^{* *}$ \\
EXC $\nrightarrow$ IR & -0.99 & 1.47 & 0.32 \\
IR $\nrightarrow$ EXC & 0.43 & 2.80 & 0.66 \\
IR $\nrightarrow$ CAD & 1.90 & 4.17 & $0.05^{* *}$ \\
CAD $\nrightarrow$ IR & 0.38 & 2.75 & 0.69 \\
\hline
\end{tabular}

Note: Symbol $\nrightarrow$ denotes "does not cause", * represents a rejection of the null hypothesis and significance; Zbar statistics represent statistics for homogenous noncausality. W-stat is wald statistics, ${ }^{* * *},{ }^{* *}$ representing significance at $1 \%$ and $5 \%$, respectively. The lag length is 2 .

There are different hypotheses about the relationships of fiscal deficit (FD) and current account deficit (CAD) recommended by different economic theories. First, an increase in fiscal deficit puts upward pressure on the interest rate. This, in turn, induces an increase in 
capital inflows and appreciation in the exchange rate. This channel ultimately exacerbates the trade balance and is referred to as a twin deficit. Second, an increase in the fiscal deficit will not alter the capital inflows and level of aggregate demand. Third, the situation where the current account deficit can generate a fiscal deficit can occur. This is known as the current account targeting hypothesis (CATH). The results of the DH Granger causality test for twin deficit hypotheses are presented in Table 6 . Probability values of $1 \%, 5 \%$, and $10 \%$ represent the rejection of the null hypothesis $\left(\mathrm{H}_{0}\right)$, meaning that $\mathrm{X}$ does not homogenously cause $Y$. The current account deficit does cause a fiscal deficit. However, the fiscal deficit does not cause a current account deficit.

Surprisingly, CAD does cause FD, which supports the current account targeting hypothesis (CATH). This leads to reverse causality from the current account deficit to the fiscal deficit. The CATH points to the need to monitor the economy's external competitiveness to assess import and export flows. Several factors may be responsible for the reverse causality relationship from the current account deficit to the fiscal deficit in ASEAN, such as the level and composition of external liabilities, the flexibility of macroeconomic policies, and the banking system. All these factors can influence the sensitivity of the current accounts. ASEAN can use fiscal policy to adjust the external balance. In other words, the government can eradicate the unfavorable current account position by using the fiscal deficit as a tool. The CAD is a result of increased imports, which increases government expenditures and generates a fiscal deficit.

Moreover, the interest rate causes CAD. A high interest rate can increase capital inflows in the region, which tends to appreciate the currency value and high imports, resulting in a CAD. Interestingly, IR causes FD, meaning that IR dynamics can bring changes in FD. On the other hand, CAD does cause EXC. In short, the current account deficit does cause FD and EXC, while the interest rate causes the current account deficit and fiscal deficit. The interest rate moderates the relationship between CAD and FD.

Previous studies $[8,16,32,34]$ have analyzed ASEAN fiscal causal and twin deficit hypotheses using different methods, such as the autoregressive distributed lag model, GMM model, and Vector error correction model, and have yielded different results due to different data span and different methods. This study revealed different results from previous studies based on the modified models. The investigation on the impact of fiscal deficit on economic growth is not enough until the consequence of fiscal deficit is not investigated. Therefore, this study investigated the consequences of fiscal deficit and disclosed that a fiscal deficit could result from inflation, political stability, current account deficit, and outstanding debt.

\section{Conclusions and Policy Suggestions}

This study has analyzed fiscal causal and twin deficit hypotheses, fiscal deficit, inflation, deficit financing, and political stability. The fiscal causal consideration and long-run examination are considered for a sustainable economic policy. GE contributes to GDP with a high sustainability ratio relative to GR. The fluctuations in revenue level may influence economic growth [69]. The GR has an inverse relationship with the economic growth of ASEAN. Thus, authorities can face challenges to stabilize the economy if expenditures persistently increase relative to revenues; for example, ASEAN is facing COVID challenges, so authorities cannot raise other developmental expenditure levels. Ultimately, in this sensitive situation, the public is demotivated to pay taxes, which leads to a low level of revenues. The two-way association, also known as the fiscal synchronization hypothesis, is supported in the ASEAN economies. In the short run, GR and GE can tackle the problem of a persistent fiscal deficit. The study also concluded a bidirectional association between GE-GDP and GR-GDP, which confirms that the member states of ASEAN can utilize revenues and expenditures to accelerate economic growth and assure well-organized allocation and utilization of resources to boost sustainable economic growth. The revenues can be influential on economic growth in the short run. An increase in GDP can increase expenditures and revenues due to the Keynesian multiplier effect [70]. 
In analyzing twin deficit hypotheses as one of the consequences of alarming fiscal deficit, the findings disclosed the unidirectional relationship from the current account deficit to fiscal deficit, known as reverse causality. The government can target external balance by using fiscal policy as an instrument. The interest rate is having moderating effects for FD and CAD as it does cause FD and CAD. The dynamics in interest rate can affect the capital inflows, making the exchange rate more volatile, and last, external imbalances can occur. In ASEAN, the interest rate can be a targeted variable for valuable policy implementations.

Furthermore, there is a long-run relationship between CAD and FD, but there is no evidence for a short-run relationship between the tested variables. Moreover, this study revealed that the fiscal deficit and money supply as a central bank tool could generate inflation in the long run. When the government increases borrowing/debt to fill the gap between government expenditures and government revenues, it leads to an increased money supply in the market, which generates inflation in the economy. Political stability is impactful and significant in the short run and can generate inflation. After discussing all the findings, this study reveals that the fiscal deficit of ASEAN is alarming on the grounds of political stability, government revenues, and inflation. The fiscal deficit of ASEAN is not alarming in terms of trade balance as it does not cause a current account deficit. While other factors, such as the impact of political stability, the inverse nature of government revenues, and fiscal deficit along with its sources of deficit financing, can generate inflation, making the fiscal deficit alarming in ASEAN.

After concluding the findings, this study recommends a few policies for ASEAN, including the fiscal policy implementation according to the fiscal synchronization hypothesis, which means that fiscal decision is based on two main components government expenditures and revenues; the fiscal decision should consider the cost-effectiveness as government expenditures, and government revenues are working simultaneously in the economies. ASEAN can minimize its fiscal deficit by implementing fiscal policy using fiscal synchronization. While analyzing twin deficit analysis, this study suggests that exchange rate dynamics and fiscal deficit can be targeted in a long-run policy for making the current accounts favorable. The fiscal deficit in ASEAN is relatively sensitive towards the current account deficit. Thus, the authorities should target the current account deficit as findings indicate that the current account deficit is causing a fiscal deficit.

The fiscal deficit can be inflationary if ASEAN stays reliant on debt. For instance, using domestic sources, money supply by the central banks, and domestic borrowing can be less inflationary for ASEAN. Carlos [71] argued about the fiscal constraint and inflation in the context of financing COVID-19. The government can minimize its expenditures and not increase debt levels. The central banks can buy new securities from the treasury to finance exceptional spending. This policy would not conflict with inflation constraints. Moreover, money supply conflicts with fiscal constraints but avoids the increases in outstanding debt and validates inflation.

Author Contributions: Conceptualization, H.K. and M.M.; methodology, H.K. and R.B.; validation, M.M., H.K. and R.B.; formal analysis, H.K. and M.M.; investigation, H.K. and R.B.; data curation, H.K.; writing—original draft preparation, H.K.; writing—review and editing, M.M. and R.B.; supervision, M.M.; project administration, M.M.; funding acquisition, M.M. All authors have read and agreed to the published version of the manuscript.

Funding: This research was funded by UNIVERSITI TEKNOLOGI PETRONAS, Malaysia, grant numbers 015LC0-194.

Data Availability Statement: Publicly available datasets from World Bank and Asian Development Bank Database were analyzed in this study. The data can be found here: World bank: https: / / data.worldbank.org/ (accessed on 10 February 2021); ADB: https:/ / data.adb.org/ (accessed on 10 February 2021).

Acknowledgments: This study is supported by Universiti Teknologi PETRONAS, Malaysia, and the Institute of Management Sciences (IM I Sciences), Pakistan. 
Conflicts of Interest: The authors declare no conflict of interest. The funders had no role in the design of the study; in the collection, analyses, or interpretation of data; in the writing of the manuscript, or in the decision to publish the results.

\section{References}

1. Hicklin, M.J.; Robinson, M.D.; Singh, M.A. Macroeconomic Issues Facing ASEAN Countries; International Monetary Fund: Washington, WA, USA, 1997.

2. Ngo, M.N.; Nguyen, L.D. The Role of Economics, Politics and Institutions on Budget Deficit in ASEAN Countries. J. Asian Financ. Econ. Bus. 2020, 7, 251-261. [CrossRef]

3. Fitriaini, R. Fiscal Policy Behaviour in ASEAN: Countercyclical or Procyclical? KnE Soc. Sci. 2020, 170-178. [CrossRef]

4. Syadullah, M. Governance and tax revenue in ASEAN countries. J. Soc. Dev. Sci. 2015, 6, 76-88. [CrossRef]

5. Tang, H.C.; Liu, P.; Cheung, E.C. Changing impact of fiscal policy on selected ASEAN countries. J. Asian Econ. 2013, 24, $103-116$. [CrossRef]

6. Baharumshah, A.Z.; Lau, E.; Fountas, S. On the sustainability of current account deficits: Evidence from four ASEAN countries. J. Asian Econ. 2003, 14, 465-487. [CrossRef]

7. Chen, L. ASEAN in the Digital Era: Enabling Cross-border E-commerce. In Developing the Digital Economy in ASEAN; Routledge: London, UK, 2019; pp. 259-275.

8. Lau, W.-Y.; Yip, T.-M. The Nexus between Fiscal Deficits and Economic Growth in ASEAN. J. S. Asian Econ. 2019, 36, 25-36. [CrossRef]

9. Tung, L.T. The effect of fiscal deficit on economic growth in an emerging economy: Evidence from Vietnam. J. Int. Stud. 2018, 11, 191-203. [CrossRef]

10. Schwarzer, J.A. Retrospectives: Cost-Push and Demand-Pull Inflation: Milton Friedman and the "Cruel Dilemma". J. Econ. Perspect. 2018, 32, 195-210. [CrossRef]

11. Cochrane, J.H. The fiscal roots of inflation. Rev. Econ. Dyn. 2021. [CrossRef]

12. Laiprakobsup, T. Democracy, economic growth and government spending in public health in Southeast Asia. Int. J. Dev. Issues 2019, 18, 70-87. [CrossRef]

13. Nabi, G.; Bhat, K.; Ghazanfar, F. Does Budget Deficit and Political Stability Effect Real Exchange Rate in South Asian Countries. Glob. Manag. Sci. Rev. 2021, 6, 26-38.

14. Croissant, A.; Lorenz, P. Comparative Politics of Southeast Asia; Springer: Cham, Switzerland, 2018.

15. Karim, Z.A.; Asri, N.M.; Abdullah, A.A.-H.; Antoni, A.; Yusoff, Z.Z.M. The relationship between federal government revenue and spending: Empirical evidence from Asean-5 countries. Econ. J. Emerg. Mark. 2006, 11. [CrossRef]

16. Magazzino, C. The Relationship between Revenue and Expenditure in the ASEAN Countries. East Asia 2014, 31, $203-221$. [CrossRef]

17. Saysombath, P.; Kyophilavong, P. The causal link between spending and revenue: The Lao PDR. Int. J. Econ. Financ. 2013, 5, 111. [CrossRef]

18. Jalil, A.Z.A.; Harun, H. Fiscal decision and fiscal performance: The case of Kelantan and Penang. Procedia Econ. Financ. 2012, 1, 193-202. [CrossRef]

19. Jiranyakul, K. Is the Thai Government Revenue-Spending Nexus Asymmetric? 2018. Available online: https://ssrn.com/ abstract=3083886 (accessed on 5 March 2021).

20. Narayan, P.K. The government revenue and government expenditure nexus: Empirical evidence from nine Asian countries. $J$. Asian Econ. 2005, 15, 1203-1216. [CrossRef]

21. Obeng, S. A causality test of the revenue-expenditure nexus in Ghana. ADRRI J. Arts Soc. Sci. 2015, 11, 1-19.

22. Mele, M.; Quarto, A.; Abbafati, C. On the Fiscal Policy in Malaysia: An Econometrical Analysis Between the Revenue and Expenditure. Res. World Econ. 2020, 11. [CrossRef]

23. Chang, H.-C.; Huang, B.-N.; Yang, C.W. Military expenditure and economic growth across different groups: A dynamic panel Granger-causality approach. Econ. Model. 2011, 28, 2416-2423. [CrossRef]

24. Lee, J.C.; Won, Y.J.; Jei, S.Y. Study of the Relationship between Government Expenditures and Economic Growth for China and Korea. Sustainability 2019, 11, 6344. [CrossRef]

25. Wu, S.-Y.; Tang, J.-H.; Lin, E.S. The impact of government expenditure on economic growth: How sensitive to the level of development? J. Policy Modeling 2010, 32, 804-817. [CrossRef]

26. Afonso, A.; Furceri, D. Government size, composition, volatility and economic growth. Eur. J. Political Econ. 2010, 26, 517-532. [CrossRef]

27. Dudzevičiūtè, G. Government expenditure and economic growth in the European Union countries. Int. J. Soc. Econ. 2018, 45, 372-386. [CrossRef]

28. Durevall, D.; Henrekson, M. The futile quest for a grand explanation of long-run government expenditure. J. Public Econ. 2011, 95, 708-722. [CrossRef]

29. Tan, C.-T.; Mohamed, A.; Habibullah, M.S.; Chin, L. The Impacts of Monetary and Fiscal Policies on Economic Growth in Malaysia, Singapore and Thailand. South Asian J. Macroecon. Public Financ. 2020, 9, 114-130. [CrossRef] 
30. Samudram, M.; Nair, M.; Vaithilingam, S. Keynes and Wagner on government expenditures and economic development: The case of a developing economy. Empir. Econ. 2009, 36, 697-712. [CrossRef]

31. Pontoh, W. The Capital Structure: Is Debt just a Policy or Requirement? Eur. Res. Stud. 2017, 20, 128. [CrossRef]

32. Baharumshah, A.Z.; Ismail, H.; Lau, E. Twin Deficits Hypothesis and Capital Mobility: The ASEAN-5 Perspective. J. Pengur. 2009, $29,15-32$.

33. Lau, E.; Mansor, S.A.; Puah, C.-H. Revival of the Twin Deficits in Asian Crisis-Affected Countries. Econ. Issues 2010, 15, 29-53.

34. Magazzino, C. The Twin Deficits in the ASEAN Countries. Evol. Inst. Econ. Rev. 2020, 1-22. [CrossRef]

35. Bucevska, V. Testing the Twin Deficit Hypothesis: Evidence from the Republic of North Macedonia. Bus. Syst. Res. Int. J. Soc. Adv. Innov. Res. Econ. 2020, 11, 45-62.

36. Janko, Z. On the relationship between the current account and the fiscal balance: The case of Canada. N. Am. J. Econ. Financ. 2020, 54, 101241. [CrossRef]

37. Vishal, S.; Ashok, M. Revisiting the Dynamics of the Fiscal Deficit and Inflation in India: The Nonlinear Autoregressive Distributed Lag Approach. Экономика Региона 2021, 17, 318-328.

38. Baldacci, E.; Gupta, S.; Mati, A. Political and fiscal risk determinants of sovereign spreads in emerging markets. Rev. Dev. Econ. 2011, 15, 251-263. [CrossRef]

39. Cox, G.W.; Weingast, B.R. Executive constraint, political stability, and economic growth. Comp. Political Stud. 2018, 51, 279-303. [CrossRef]

40. Feng, Y. Political freedom, political instability, and policy uncertainty: A study of political institutions and private investment in developing countries. Int. Stud. Q. 2001, 45, 271-294. [CrossRef]

41. Franzese, R.J., Jr. Macroeconomic Policies of Developed Democracies; Cambridge University Press: Cambridge, UK, 2002.

42. Telatar, E.; Telatar, F.; Cavusoglu, T.; Tosun, U. Political instability, political freedom and inflation. Appl. Econ. 2010, 42, 3839-3847. [CrossRef]

43. Aisen, A.; Veiga, F.J.; Does Political Instability Lead to Higher Inflation? A Panel Data Analysis. J. Money Credit Bank. 2006, 1379-1389. Available online: https:/ / www.jstor.org/stable/3839011 (accessed on 5 March 2021).

44. Asteriou, D.; Siriopoulos, C. The role of political instability in stock market development and economic growth: The case of Greece. Econ. Notes 2000, 29, 355-374. [CrossRef]

45. Asteriou, D.; Lalountas, D.A.; Siriopoulos, C. A Small Macro-Econometric Model for Greece: Implications about the Sustainability of the Greek External Debt. 2011. Available online: https:/ /ssrn.com/abstract=1884905 (accessed on 5 March 2021).

46. Ridzuan, M.R.; Abd Rahman, N.A.S. The Deployment of Fiscal Policy In Five ASEAN Countries in Dampening The Impact of COVID-19. J. Emerg. Econ. Islamic Res. 2021, 9, 16-28.

47. Abdullah, H.; Yien, L.C.; Khan, M.A. The impact of fiscal policy on economic growth in ASEAN-5 countries. Int. J. Supply Chain Manag. 2019, 8, 754 .

48. Basri, M.C.; Hill, H. The Southeast Asian economies in the age of discontent. Asian Econ. Policy Rev. 2020, 15, 185-209. [CrossRef]

49. Hil, H. Southeast Asian macroeconomic management: Pragmatic orthodoxy? Masy. Indones. 2017, 39, 459-479.

50. Van, V.B.; Sudhipongpracha, T. Exploring government budget deficit and economic growth: Evidence from Vietnam's economic miracle. Asian Aff. Am. Rev. 2015, 42, 127-148. [CrossRef]

51. Dumitrescu, E.-I.; Hurlin, C. Testing for Granger Non-causality in Heterogeneous Panels. Econ. Model. 2012, 29 , 1450-1460. [CrossRef]

52. Baharumshah, A.Z.; Lau, E. Dynamics of Fiscal and Current Account Deficits in Thailand: An Empirical Investigation. J. Econ. Stud. 2007, 34, 454-475. [CrossRef]

53. Catão, L.A.V.; Terrones, M.E. Fiscal deficits and inflation. J. Monet. Econ. 2005, 52, 529-554. [CrossRef]

54. Ali, K.; Khalid, M. Sources to finance fiscal deficit and their impact on inflation: A case study of Pakistan. Pak. Dev. Rev. 2019, 58, 27-43. [CrossRef]

55. Banerjee, A.; Marcellino, M.; Osbat, C. Some cautions on the use of panel methods for integrated series of macroeconomic data. Econom. J. 2004, 7, 322-340. [CrossRef]

56. Im, K.S.; Pesaran, M.H.; Shin, Y. Testing for unit roots in heterogeneous panels. J. Econom. 2003, 115, 53-74. [CrossRef]

57. Levin, A.; Lin, C.-F.; Chu, C.-S.J. Unit Root Tests in Panel Data: Asymptotic and Finite-Sample Properties. J. Econom. 2002, 108, 1-24. [CrossRef]

58. Baltagi, B.H. Econometric Analysis of Panel Data; Springer Nature: Cham, Switzerland, 2021.

59. Pedroni, P. Panel cointegration: Asymptotic and finite sample properties of pooled time series tests with an application to the PPP hypothesis. Econom. Theory 2004, 20, 597-625. [CrossRef]

60. Pesaran, M.H.; Shin, Y.; Smith, R.P. Pooled mean group estimation of dynamic heterogeneous panels. J. Am. Stat. Assoc. 1999, 94, 621-634. [CrossRef]

61. Marques, A.C.; Fuinhas, J.A.; Pais, D.F. Economic growth, sustainable development and food consumption: Evidence across different income groups of countries. J. Clean. Prod. 2018, 196, 245-258. [CrossRef]

62. Quintos, C.E. Sustainability of the deficit process with structural shifts. J. Bus. Econ. Stat. 1995, 13, 409-417.

63. Can, C.K.; Bağdadioğlu, N. Quantifying the Sustainability of Public Debt: Time-Varying Evidence from a Developing Country; Cambridge Scholars Publishing: Newcastle, UK, 2021. 
64. Gkillas, K.; Konstantatos, C.; Siriopoulos, C. Uncertainty Due to Infectious Diseases and Stock-Bond Correlation. Econometrics 2021, 9, 17. [CrossRef]

65. Lopez, L.; Weber, S. Testing for Granger Causality in Panel Data. Stata J. 2017, 17, 972-984. [CrossRef]

66. Aziz, M.A.; Habibullah, M.S.; Azman-Saini, W.; Azali, M. Testing for causality between taxation and government spending: An application of Toda-Yamamoto approach. Pertanika J. Soc. Sci. Humanit. 2000, 8, 45-50.

67. Cipollini, A. Testing for government intertemporal solvency: A smooth transition error correction model approach. Manch. Sch. 2001, 69, 643-655. [CrossRef]

68. Asongu, S.A. Correcting inflation with financial dynamic fundamentals: Which adjustments matter in Africa? J. Afr. Bus. 2014, 15, 64-73. [CrossRef]

69. Brueckner, M.; Dabla-Norris, E.; Gradstein, M.; Lederman, D. The rise of the middle class and economic growth in ASEAN. J. Asian Econ. 2018, 56, 48-58. [CrossRef]

70. Farhi, E.; Werning, I. Fiscal multipliers: Liquidity traps and currency unions. In Handbook of Macroeconomics; Elsevier: Amsterdam, The Netherlands, 2016; Volume 2, pp. 2417-2492.

71. Bresser-Pereira, L.C. Financing COVID-19, inflation and fiscal constraint. Braz. J. Political Econ. 2020, 40, 604-621. [CrossRef] 